\title{
State, identity, and the politics of music: Eurovision and nation-building in Azerbaijan
}

\author{
Murad Ismayilov*1 \\ University of Cambridge \& Azerbaijan Diplomatic Academy
}

(Received 12 March 2012; final version received 28 June 2012)

\begin{abstract}
Albeit often - and fairly - degraded in the world of high culture as a populist and politicized representation of music, the Eurovision Song Contest (ESC) - by sheer virtue of the populist and politicized nature of its essence - stands among the most consequential cultural encounters to which post-independence Azerbaijan has been exposed, in that the extent to which Baku's victory in the ESC-2011 - and the further developments this victory has generated - can potentially impact on, and contribute to, the very process of nation-building and national identity formation, with which this post-Soviet Muslim-majority country is currently struggling, is unparalleled by any of the state's earlier encounters of the kind. This paper focuses on, and examines, four intimately related ways in which the ESC and Azerbaijan's successful involvement with the latter worked to interfere with the country's nation-building: as a dubious factor in the evolution of the Western sense of self among Azerbaijanis; as a unifying force within the structure of the country's rapidly maturing civil society; as a medium working to open up a channel through which Western popular cultural elements could interfere with the evolving dynamics of, and work to globalize, indeed de-endogenize, indigenous Azerbaijani culture, on one hand, and unify the discursive realm within which the country's cultural domain is to further evolve, on the other; and, finally, as an important element serving to decouple the evolving processes within the country's cultural domain from the unfolding dynamics of conflict settlement and hence conducive to the diversification of public discourse in Azerbaijan.
\end{abstract}

Keywords: Azerbaijan; Eurovision; politics of music; national identity; culture; cultural diplomacy; civil society

Azerbaijan's victory in the Eurovision Song Contest's 2011 cycle and, by virtue of that victory, the country's hosting of the contest in 2012 have generated ample discussion and divergent reactions both within the country and abroad. Eurovision boasting massive audience participation every year, the ESC-2012, in particular, amounted to "an incredible influx of attention for a country that [was] known, if at all, as Europe's backwater" (Erickson; also Goble; "Can Eurovision Burnish"); a reality that made the staging of this music competition in Baku - to echo Roland Kobia, head of the EU delegation in Azerbaijan - "a landmark event" in the history of the young nation (Antidze). Among those involved in the discussions around the ESC's two latest editions, many focused on the implications the victory and the effects it worked to produce had or might potentially have for the country's domestic polity or indeed its international standing, with further democratization projected to progress (e.g. Amani) and the international attention towards the country set to grow. Indeed, Azerbaijan's successful involvement with Eurovision's 2011 and 2012 cycles and a one-year period linking the two together have

*Email: murad.ismayilov@cantab.net or mismayilov@ada.edu.az 
generated a number of informative, indeed promotional, articles in Western media about, and attracted a growing number of disparate individuals to, the country, its cultural heritage and natural riches, on one hand, and have drawn greater international attention to the country's pending problems, including with human rights, on the other. ${ }^{2}$ The growth in attention to Azerbaijan was also reflected in the rapidly surging number of Internet searches conducted on the country. According to the information from the Internet Forum of Azerbaijan, the queries on Azerbaijan on Google increased eightfold during one month after the country's Eurovision victory in 2011, while the searches on Baku doubled over the same period ("Interest for Azerbaijan Heightened"). According to Breaking Travel News, in turn, interest in Azerbaijan grew by over 4,000\% on TripAdvisor following the country's win in the ESC-2011, a tremendous increase indeed ("Interest in Azerbaijan Up"). In like manner, according to Google Insights for Search, Baku's hosting of Eurovision in May 2012 generated a renewed outburst of interest in the country, rendering search queries on Azerbaijan among the ten most popular on Google in the last ten days of May, the peak of the country's internet popularity falling on the day when the Eurovision final was held on May $26 .^{3}$

This being so, few, if any at all, have reflected on the impact Azerbaijan's victory in the ESC-2011 - and the further developments this victory has generated - may have on the very process of nation-building and national identity formation, with which this post-Soviet country straddling a fine line between East and West is currently struggling. The failure of observers to attend to this aspect is particularly surprising given the way officials were using it at home as they prepared to host the Eurovision final in Baku in 2012, the prerogative of the victor country. ${ }^{4}$ To mend this omission, the article focuses on, and examines, four intimately related ways, in which the ESC and Azerbaijan's successful involvement with the latter worked to interfere with the country's nation-building: as a dubious factor in the evolution of the Western sense of Self among Azerbaijanis; as a unifying force within the structure of the country's rapidly maturing civil society; as a medium working to open up a channel through which Western popular cultural elements could interfere with the evolving dynamics of, and work to globalize, indeed de-endogenize, indigenous Azerbaijani culture on one hand, and unify the discursive realm within which the country's cultural domain is to further evolve, on the other; and, finally, as an important element serving to decouple the evolving processes within the country's cultural domain from the unfolding dynamics of conflict settlement and hence conducive to the diversification of public discourse in Azerbaijan. While the final product in which the evolutionary dynamics within either of the latter four "fields of influence" are meant to result lies at this stage within the universe of the unknown (and hence any argument towards the latter belongs in the realm of speculation) and - given the unceasing nature of social processes - may permanently reside therein, social developments and state practices emerging as a fluid and continuously instantiated function of the latter dynamics - their nature and unintended spin-offs - are already having a discernible impact on the direction in which the country's post-Soviet national identity has evolved to progress. As such, each of the four directions in which Azerbaijan's involvement with the ESC works or is likely to work its effects on the country's ideational realm of nation building deserves closer attention and scrutiny.

\section{Eurovision and Azerbaijan's self-perception}

First, and most obvious, the country's very participation in Eurovision being undoubtedly, if not solely, an expression of its "assertion of modernity and [its] claim to membership in Europe and the West" (Raykoff and Tobin), the contest - and the processes it generated - 
has played, or is likely to play, a dubious role as a factor in the evolution of the Western sense of Self among Azerbaijanis. On one level, Azerbaijan's successful involvement with the ESC - its victory in 2011 and its effectual staging of the contest in $2012^{5}$ - has worked to dramatically strengthen the sense of European, indeed Western, identity amidst a certain stratum of the country's society and its elite alike - the latter boasting both the Western character of the songs performed and the Western guise of its performers. Indeed, Azerbaijan's winning entry for Eurovision-2011 - a Western-style pop song in itself - was written, its verses and music alike, not by an Azerbaijani - as one might have expected - but a Swedish-UK combined trio of Stefan Örn, Sandra Bjurman, and Iain James Farquharson; with yet another Swedish national, Rennie Mirro, involved with the Azerbaijani team all along the preparation process as their chief choreographer, and, finally, four other Swedes acting as backing vocalists during the actual performance. To be sure, it was only for Azerbaijan's ESC-2008 entry - the very first time the country joined the contest - that music and the text were actually written by Azerbaijani nationals. ${ }^{6}$

This upgraded - Western - sense of Self, however, limited as it is to the engaged few and based on a superficial projection of one successful experience of, and cultural engagement with, Europe onto the image of the overall population, is likely to have been tested in May 2012 as Baku moved to host the ESC and as the myriad of diverse groups of European fans the latter attracted came to flood the Azerbaijani capital: the time when an abstract notion of what it actually means to be European - on a daily routine basis - was put to practical, real-life, examination. Still more importantly, the learning experience on the part of the local populace, and an exercise at critical self-appraisal that is certain to attend the latter, is likely to continue as the regular stream of tourists visiting the country steadily grows and the range of countries they represent comes to widen; the near future tendency Azerbaijan's 2012 success as Eurovision host is expected to generate. That is, as increasingly broader sections of the Azerbaijani populace obtain a first-time opportunity to actually "live" the European culture in practice, many are likely to engage in a self-assessment exercise - re-appraisal of the many imaginaries, of themselves and others, they have come to construe over time, that is - one meant to check for the compatibility of values, habits and traditions between what they would perceive as their national cultural Self and the European - Western - Other.

While Azerbaijan is certainly not a "[stranger] to hosting major crowd-pulling events" (Gurbanov) and has previously organized many large-scale - internationally significant events, in sports and culture alike, ${ }^{7}$ limited in the social group those aimed to target, few if at all have managed to attract an audience - television and live alike - as diverse along the national and class lines as the one the Eurovision song contest was sure to engage in May 2012. The type of sports events the country hosted being individual in nature and the cultural/musical mass performances it organized being either classical or traditional genres, they all were limited to an audience with a particular taste, and hence of a particular high-class - social standing. ${ }^{8}$ None, therefore, was a massive event in the real sense of the word, in that none was capable of pulling together people from different social strata, either within or outside the country. That being so and with Eurovision being one of the most visited international events of its kind, Baku's hosting of the ESC-2012 came to mark the first massive encounter of the country's local, if urban, population with a broadly diverse range of Western populace, including the middle-class and lower-middle-class representatives of it. In more concrete terms, the ESC's $57^{\text {th }}$ cycle staged in Baku worked to generate - for one week in May 2012 at least - a live audience of six to seven thousand international fans, by far the highest number and the most diverse group of one-time visitors the Azerbaijani capital has ever had a chance to witness. Indeed, 
even though the latter number of tourists to have traveled to the Azerbaijani capital during the Eurovision week ended up at a lower end of the range of the expected, ${ }^{9}$ the Eurovision week in May 2012, by all means, stands to embody "the largest event and the largest number of tourists that Baku ha[d] [hitherto] hosted." 10

Still more importantly and as one post-Eurovision study makes clear, the ESC - "the world's largest non-sporting television event" (Neukirch) - boasting over 100 million television audience annually and widely viewed as one of Europe's favorite TV-shows and, indeed, among its few "institutions to generate any popular enthusiasm" (Ewing), "[t]he most obvious benefit" Baku derived from hosting the 2012 edition of it "was that it has put Azerbaijan on the map in a way that no other event could do," the latter certain to contribute to the country's growing as an object of heightened tourist attention in the near future. ${ }^{11}$ As one observer aptly noted, Azerbaijan's ESC-2011 “victory ensure[d] that, for one week in 2012 at least, the capital city of Baku [was] in the minds of the 125 million to 150 million viewers who tune[d] into the competition" ("Can Eurovision Burnish").

To be sure and perhaps not surprisingly, among the six to seven thousand fans who visited Baku during the Eurovision week in May 2012, the majority were nationals of neighbouring and culturally like polities - Georgia, Iran, Turkey, Russia, and those of Central Asia, that is - thus falling short of contributing in any notable way to the dynamics of cultural learning on the part of the local populace ("The Number of Tourists"). While the latter reality was in many ways derivative of the extent of the infrastructural and logistical ease of getting to the country (e.g. the availability of direct flights), crossing its borders (the specific nature of bilateral visa regimes and particular costs associated with them), and staying therein (accommodation pricing), however, as the government successfully works to wipe away the infrastructural and logistical hurdles of the sort and as the effects of Eurovision and concomitant efforts the state invests to this effect come to inspire a greater degree of tourist interest in the region, the range of countries the tourists come to represent is certain to gradually widen in the coming years. ${ }^{12}$

One important impact this first-time large-scale encounter with, and a deeper awareness of, European/Western "routine" culture - and the follow-up encounters of the kind the expected growth in the tourist flow is likely to make possible - are certain to make on Azerbaijan's nation-building project - an impact, that is, hinged on the reaction to the "alien" culture those contacts come to generate amongst the country's populace at large - is to reinforce, or contribute to, the evolution of the national identity along either of two alternative pathways; one predicated on the acceptance, indeed the celebration, of Western values as an essential part of Self, and the other rooted in an outright rejection thereof as an important Other against which the nation's indigenous culture is to be secured and further buttressed. To be sure, both of these cognitive preferences are engrained in social conscience - at different levels in different spaces - the country widely perceived, by the governing elite and amongst the society alike, as "a crossroads between East and West" and the capital hailed by many as "the easternmost city of Europe and the westernmost city of Asia" (McLaughlin) with "Old Baku," to cite Eldar Gasimov, the male representative of Azerbaijan's winning Eurovision duo, "virtually screaming that you are in the East," while "outside the old city a real Europe" begins ("Eurovision Winner Eldar"). The workings of the processes in the run-up to, in the course of and following the actual holding of the ESC-2012, then, are certain to contribute to the growth of, indeed reinforce, the national bent towards either of the latter two choices, the direction of the cognitive tilt at the societal level to be conditioned by the reaction a day-to-day contact with the "alien" incomers - and the perceived extent of 
compliance the values that the latter espouse enjoy with indigenous cultural standards works to catalyze among the local community. While the particular nature of individualized reactions those contacts work to produce are not likely to be immediately palpable, lying - and evolving - deep in the people's psyche, they will gradually find expression through the multitude of attitudes on diverse issues of varied importance the local (and localized) groups come to shape and/or adjust as they move along from one encounter to another, the objects of the many of their attitudes ranging from the perceived legitimacy of men's wearing shorts in public places, for example, to specific practices of particular states.

These encounters, and the effects they are bound to produce, are certain to be significantly different from many scattered individual experiences of Western exposure many Azerbaijanis studying, working or simply travelling abroad have hitherto had, the difference stemming precisely from the former's being a collective experience of engagement with the Western populace, and one lived at home, thus generating the conditions for a direct and collective comparison of "them" and "us." That is, the effects these contacts are going to produce will likewise be collective and, as such, more likely to diffuse into the realm of national identity and affect its overall dynamics, rather than remaining limited to a circumscribed locus of a handful of scattered individual identities only. In like manner, the encounters of the kind - including those Eurovision as lived experience worked to engender - also stand to vary - in terms of the breadth and the depth of perceptual consequences that are likely to result from them (the latter bound to be nation-wide on one hand and formative, in the longer run, of national identity on the other) - from different kinds of individual experiences of virtual, media-mediated, involvements with Western life and culture most Azerbaijanis had by now had (including by virtue of their earlier exposure to the televised versions of the ESC; ESC as a "media event," that is), ${ }^{13}$ for - collective as these encounters are certain to be - they also enable practical contact with, and live observation of, what for many Azerbaijanis has hitherto lied within the abstract, a priori, realm of fantasy and imagination.

Furthermore and apart from its being an important factor in the evolving sense of self at a societal level, the ESC - and the ensuing processes - are also likely to bear directly on the cognitive choice at the elite and intelligentsia level and hence be formative - concomitant and in combination with other attendant factors - of Azerbaijan's foreign policy as well, the latter effect to be in large measure derivative of the reaction - favourable or adverse - the country, its cultural standing and the extent of, indeed further prospects for, modernization it has by now achieved and is keen to exhibit ${ }^{14}$ receive from the many Western journalists and observers, including those who came to pour into the ESC-2012 host capital during and around the days of the show; the latter's numbers only comparable to those of journalists/observers visiting Baku during the days of elections, presidential, parliamentary and municipal alike. ${ }^{15}$

While the societal reaction to, and the locals' feelings about, their encounters with Western "populace" are likely to be hinged on the seemingly most trivial observations, the latter's focus ranging from the overall appearance and everyday lifestyle of Western visitors to their particular understanding of gender ${ }^{16}$ and their attitude to, indeed more engaged approach to, entertainment and leisure; the elite reaction and that of the intelligentsia is sure to pivot on their perception of the extent to which the post-ESC-2012 Western reflections on the country - and Western reactions certain to follow the country's future encounters of the kind - will have been derived from, and rooted in, an Orientalist construction of the nation's present realities, rather than what the elite would qualify as an objective analysis of the country's up-to-date status, as well as on their assessment of 
the degree to which the international appreciation of the country's successes on the path towards modernization would balance with a more critical appraisal. ${ }^{17}$ That is and while the immediate effects Baku's hosting of Eurovision had at the societal level are nearly impossible to gauge (and could only be accounted for at an anecdotal level of individual cases), the relevant dynamics at the elite level is discernible already at this stage, the latter most vividly expressed, among other developments, in the government's reaction to, and its perception of, the resolution "on the human rights situation in Azerbaijan" the EU parliament adopted on May 24, 2012 (European Parliament Resolution). Although not directly linked to the ESC-2012, yet passed during the week of the latter's unfolding, the resolution - highly critical of Baku's human rights performance as it is - was widely perceived by the government - especially in light of a parallel wave of Western criticism voiced against the country's allegedly autocratic system immediately prior to and during the Eurovision week ${ }^{18}$ - as an expression of "double standards" the West employed in its pursuit of relations with, and an instrument of pressure on, Azerbaijan and, as such, as the latter's attempt to effectively undermine Baku's rising profile on the international scene. Indeed, many in Baku were quick to establish a direct linkage between the resolution and the Eurovision contest that paralleled it, citing - to echo Ogtay Asadov, the speaker of the Azerbaijani parliament - "Azerbaijan's successes," including "a very high level on which the Eurovision song contest was held in Baku," as a "cause for concern for certain forces" and, as such, as the principal reason behind the resolution. Still more notably, some government members went as far as to suggest that the resolution - and the West's biased disposition the latter allegedly embodied might prompt Azerbaijan to revise its relations with the EU's parliamentary body and ultimately result in Baku's gradually shifting away from the Euro-Atlantic path it had taken on from early days of independence. ${ }^{19}$

One way or the other and in many ways, for nations in Western Europe, Azerbaijan's ESC victory in 2011 - especially given that it followed Muslim, if nominally secular, Turkey's victory not long ago - and its hosting of the ESC-2012 - especially that the latter proved successful - will serve as, or in the least add to, what French philosopher Michel Foucault aptly termed "normalization," a complex process by virtue of which Europe's perceptual borders of Self are likely to gradually expand and its discriminatory representation of the Other could potentially get mitigated. To the extent this occurs, this perceptual shift is likely to produce reverberations reaching far beyond the confines of the polity of a single nation, effectively working to transform overall security relations between East and West, Europe and Asia, in the broader Eurasian region.

\section{Eurovision and Azerbaijan's civil society}

Second, and apart from the influence Eurovision is certain to work on Azerbaijan's selfperception, Baku's successful involvement with the ESC - and the processes the latter worked to unleash - is also likely to serve as an important factor in the country's internal societal dynamics, in that it could mould societal cohesion and act as a unifying force within the structure of the country's rapidly maturing civil society. The way it could do so is by and through devising bridges between and among otherwise insulated and culturally divergent societal clusters comprising the country's highly segregated civil society.

Indeed, in many ways the Azerbaijani civil society is stratified between and among those who received their education abroad (this group internally divided among those who received their education in different countries, first and foremost Turkey, the United States, and Europe) and those who only studied locally (the latter group divided 
between those who received their education in the Russian language and those who studied in Azerbaijani, as well as those who studied in Turkish lyceums). With representatives of the two groups socialized in different ways - the condition of divergent socialization sustained through tightly confined networking patterns they end up following upon graduation - they evolve to espouse variant, often conflicting, models for the country's future political development (Ismayilov and Tkacik). That being so, many for whom the ESC-2012 contact with the Western populace happened to be - and those for whom subsequent encounters of the sort which the country's rising tourist potential is certain to make possible are going to become - the first-time exposure to Western culture (those that fall within the locally educated half of the Azerbaijani society, that is) are likely - through their follow-up on that experience and subsequent involvement with a non-indigenous universe of discourse by virtue of the international travels, NGO involvement, and other engagements of a similar kind - to come to develop a certain degree of association with that externally derived cognitive framework. Importantly, and indicatively, Azerbaijan's National NGO Forum moved to establish, in January 2012, a special headquarters group set to facilitate the mobilization of human resources local NGOs have in possession, the latter meant to engage with the multitude of tourists that came to flood the capital around the Eurovision week in May 2012 and work to form a positive perception of Azerbaijan among them ("An NGO 'Eurovision' Headquarters Group"). The latter endeavor, to the extent it was successful, is certain to have provided the initial mechanism by which, and facilitate the processes through which, "the international" came to interfere with nationally circumscribed identities and conceptions of the state of which the locally educated strata of society are holders and the possible trajectory of their future evolution.

The ESC-2012, therefore, and the first-time exposure to Western culture for the locally circumscribed societal clusters it worked to engender, on one hand, and future home-based encounters of the kind that are likely to follow, on the other, could work to create alternative - externally induced - internal channels of socialization, through which the many different groups within the country's population that otherwise would never meet or interact with each other will move to engage in different forms of dialogue. The latter, in turn, will serve to bridge the existing gap between and among the broadly defined - locally and foreign educated - groups, thereby contributing to the formation of a more coherent civil society and, ultimately, a uniform national identity.

\section{Eurovision and Azerbaijan's cultural field}

Third, with the ESC meant to serve as an important Western forum in which Azerbaijan tapping the indigenous cultural capital it commands - could exhibit its unique sense of Self and, by virtue of that, acquire greater social capital within the Western purview, the complex workings of the European contest, on one hand, and the effects the extended process of the country's participation therein served to produce, on the other, opened up a reverse channel through which Western popular cultural forms could interfere with the evolving dynamics of, and work to globalize, indeed de-endogenize, the content of Azerbaijani national culture, on one hand, and unify the discursive realm within which the country's cultural domain is to further evolve, on the other. While those inside, or close to, the government have generally viewed the Eurovision contest, and the ESC-2012 in particular, as part of the country's marketing strategy and, therefore, an opportunity to promote the country's culture and traditions, and by virtue of that "improve its [overall] image, ${ }^{20}$ in the West and across the globe, ${ }^{21}$ the competitive logics by which the ESC 
is guided and the Western cognitive structure in which the competition unfolds have already had an impact in the converse direction, in that they have worked to gradually westernize, indeed de-nationalize, the country's chosen entry for the ESC. That is, having made its Eurovision debut in 2008 with a song dressed in some lengthy extracts of Mugham, an archetypically Azerbaijani traditional music genre, and its 2009 entry's intro featuring the Azerbaijani national instrument tar - the latter moves reflective of the government's desire to use the ESC as an effective platform upon which to externalize its indigenous culture beyond its national borders - the further into the contest the country progressed and the better it came to grasp the logics underlying its dynamics - with the Western and lower-middle-class nature of the decision-making and result-defining audience - the fewer distinctly national elements the national entry featured, with the ESC2011 entry ending up as "not much of an Azerbaijani song" 22 at all, a conscious choice which indeed delivered the nation a much-desired victory. ${ }^{23}$

Instrumental as this choice was and meant as part of the effort to externalize the internal cultural capital the nation has in possession, it effectively worked to initiate a medium through which external, Western, cultural elements could be diffused onto, and ultimately internalized within, an Azerbaijani indigenous context. For this trend involving as it does the sacrifice of some indigenous values, appears likely to ignite further interest among the country's artistic community in the Western cultural market, with their newlyborn desire to reach out to the West and seek international recognition for their products certain to evolve hand in hand with an emerging perception that the only way to succeed in that market would be by and through westernization, that is de-indigenization, of the cultural commodity they are to exhibit; something that is apt to unleash, or intensify, the tendency towards internalization of external elements within the domestic cultural domain and, indeed, within the conceptual product into which the country's maturing national identity is to ultimately evolve. Indeed, the latter line of thought has already found a foothold within the country's cultural field. In what is a fine illustration of just that, Eldar Gasimov of Azerbaijan's winning ESC-2011 band - in an interview to the Russianlanguage Echo newspaper - admits his primary focus in a solo career he launched shortly after his Eurovision success is going to be on what he calls "international" songs, ones that would make "us" heard not only within the limits of national borders, but outside those as well ("Eurovision 2011 Winner Talked").

Notably, the fresh interest in bringing the products of indigenous cultural activity to the attention of a Western audience that the recent success of the country's many international cultural encounters, its involvement with the ESC being an important one of them, worked to ignite had by now materialized into a number of international "pilot" projects, the Fly to Baku exhibition of Azerbaijani contemporary art staged in London in January 2012 and in Paris in April of the same year being one - and so far the most salient - among the latter. ${ }^{24}$ To be sure, being in and by itself largely part of the government's broader efforts at cultural diplomacy, Azerbaijan's participation in the ESC has itself been a result of the nation's pre-existing interest in exhibiting the cultural capital it has in accrued possession beyond the national confines, on one hand, and came amidst the growing interest towards the West within the country's broader social domain, on the other. To only mention some singular manifestations of the latter structural bent, the staging of Azerbaijani mugham and/or jazz performances in the West, including by joint Azerbaijani-Western artistic teams, for example, has now evolved into a common practice. ${ }^{25}$ Similarly indicative of this societal bias, some $63 \%$ of outdoor advertising in the country towards the end of 2011 was offered in English (if often with poor spelling and grammar), with only 6\% offered in national Azerbaijani, a tendency that has only intensified over the last several 
years. ${ }^{26}$ This being so, the overall success in which the country's engagement with the ESC resulted, however, has worked - by virtue of its showcasing the possibility of "cultural acceptance" by the West ${ }^{27}$ - to further embolden those efforts, ${ }^{28}$ on one hand, and broaden up the thematic/genre basis on which those efforts would draw and diversify the kinds of agency from which the endeavours of the sort would further spring, on the other. To only mention a few examples indicative of the latter tendency, Nigar Jamal, the female representative of Azerbaijan's ESC-2011 team, quickly moved - following her Eurovision victory in 2011 - to enter a duet with a young Danish singer, Karen Viuff, to record a pop song titled "Universe" ("Danish Songwriter Headhunted"). Some others from the Azerbaijani pop music scene have slowly followed suit. Among the latter, Tunzale Aghayeva, a trendy Azerbaijani pop singer, for example, partnered up in the forerun to Eurovision's Baku-based cycle - with Nina Badrić, Croatia's ESC2012 representative, in an effort to record a joint song named "Sunrise" ("An Azerbaijani Singer To Sing a Duet"). Eldar Mansurov, a renowned Azerbaijani composer, in turn, entered into agreement with the Universal Music Publishing Group's Turkish edition in January 2012, the latter now set to represent the composer's interests and promote his music in Turkey and internationally. ${ }^{29}$

Apart from their effects the preceding analysis reflected upon, there are at least two ways in which these latter developments are likely to interfere with the evolving dynamics within the realm of Azerbaijan's rapidly emerging mainstream - state-promoted culture, on one hand, and the nation's many spatially dispersed and locally discrete indigenous cultural forms that have so far failed to find their way onto the country's mainstream culture - the elements of Ernest Gellner's "folk" culture, that is - on the other, as well as - and most importantly - with the overall nature of dynamic interaction between the two. ${ }^{30}$ That is, on one hand, the challenge that the localized expressions of indigenous cultural forms, unsuccessful as they have thus far been to gain recognition within the mainstream cultural domain, face to their existence is likely to be significantly augmented, the latter now bound to stand the pressure not only from the state's continuous, domesticized, efforts to mould a unified cultural discursive platform around which societal cohesion and national loyalties could be organized and political legitimacy formulated, but also from the state's rapidly progressing and quickly multiplying encounters with the broader universe of global culture and a multitude of exogenous influences those contacts bring to bear.

This being so and while working to unleash a channel by virtue of which the many elements of global cultural forms would come to gradually pervade the realm of the nation's folk culture, including by igniting the latter's interest in externalizing the products of its cultural creation beyond the reach of national borders (with or without national mediation) - a process, if inevitably lower in intensity, similar to transmutation the mainstream national culture is bound to live - the country's global cultural encounters of the kind, by sheer virtue of the globalizing effect they bear on the mainstream culture and its "folk" periphery alike, could potentially serve to bridge the existing gap between the two. Bearing an effect in this direction and while working to undermine the indigenous elements within the realm of both, an exposure to international cultural forms - one instantiated by the country's role in the Eurovision Song Contest, including and especially its hosting of the 2012 cycle of it - is likely to serve to mould a single pathway through which the country's state-supported mainstream and sub-national folk culture - the latter otherwise localized and discrete as it is and, as such, left utterly ignored and lacking influence of any sort within the broader realm of rapidly evolving "national" culture - will further evolve, together. Not only will the latter homogenization of the country's cultural realm imply that both of the latter two will be left exposed to the all-pervasive influences 
of global culture - with their content set to gradually and considerably internationalize but also that the two, now evolving in a single, indeed unified, discursive realm of "national" culture, will enter into a mutually constitutive process of engaging with and ultimately influencing - each other, a process meant to significantly enrich indeed, and ironically, indigenize - the ultimate product of national identity in which it is meant to eventuate.

Importantly, the extent of the homogenizing effect the country's global cultural encounters are likely to have on its overall cultural domain will largely be a function of the degree to which the divergent elements of the nation's folk culture manage to gain access to the mechanisms by which the many products of their workings could be externalized beyond the confines of their immediate localities, on one hand, and the extent of disparity between the dynamics of the latter process and the pace at which the country's mainstream culture works to progress in that direction, on the other. That is, should the country's indigenous cultural forms fail to find a way (nationally mediated or not) to gain representation within the realm of global culture as the mainstream culture's interaction with the latter moves to intensify, the state's global cultural encounters are likely to work to widen the gap between the indigenous and mainstream segments within the national cultural realm rather than curbing it, with the folk culture - at an extreme end of the range of possible outcomes - probable to gradually evolve as an oppositional force to a cosmopolitan mainstream. ${ }^{31}$

\section{Eurovision, Azerbaijan's cultural field, and foreign policy}

Fourth, and in virtue of the third effect, while Azerbaijan's cultural diplomacy - and Baku's participation in the ESC as a singular component of it - has in large measure been meant to serve the major objectives by which its foreign policy is guided and, as such, has been a function of, and an effective part of, the country's programmatic efforts to garner international support for its struggle to arrive at what it would view as a fair resolution to its two-decade conflict with Armenia over the Nagorno-Karabakh region and seven regions adjacent to it, which Armenia currently occupies; the processes that the contest, and Azerbaijan's successful participation in it, unleashed - and external modalities of socialization that those worked to arouse - could potentially serve to decouple the evolving processes within the country's cultural domain from the unfolding dynamics of conflict settlement.

In many ways - and understandably so - the complex dynamics within the domestic cultural domain in Azerbaijan, its music and literature alike, have, in large measure, been held hostage to, and were meant to serve, the country's efforts to resolve the conflict. In what is a bright manifestation of the latter linkage, as far as Baku's involvement with, and its efforts to reach out to, the United States are concerned, for example, the Karabakh Foundation - its name symbolic, and indicative, in itself - a Washington-based US charity foundation, was established in 2010, its key objective being to "increase awareness and understanding in the United States of the cultural heritage and traditions of the country of Azerbaijan, the Caucasus area, and the Karabakh region of Azerbaijan" (Altman). ${ }^{32}$ Indeed, similar to other achievements in the cultural domain, the ESC-2011 victory, too, quickly - and inevitably - came to be related to the realm of politics and, as such, hailed as yet another brick to the country's efforts to liberate the Armenia-occupied Nagorno-Karabakh region. Ganira Pashayeva, for example, an outspoken member of the Azerbaijani Parliament, stated her hope, shortly after the victory her country registered in the ESC, to see Nagorno-Karabakh as "the subject of the next celebration," and added 
she believed "that this day [was] near" (Barry; also "Member of Parliament: 'Eurovision 2011 Victory",). In similar manner, many others, including those from within the country's broader populace, rushed to draw an association between Azerbaijan's Eurovision victory and the dynamics of conflict settlement, regarding the former - and Baku's hosting of the ESC-2012 it made possible - as "a chance to attract [the attention of] the international [community] to the conflict over Nagorno-Karabakh," on one hand, and viewing the victory in the international realm of music as a precursor to the country's final "victory" in its conflict with Armenia, on the other. In many ways echoing Pashayeva's statement above, a refugee woman from Lachin, an Azerbaijani district currently occupied by Armenia, for example, exclaimed in happiness as she heard the news of her country's success in the Eurovision contest's 2011 edition: "The Azerbaijani nation deserves a victory. [The number of victories we are able to register is continuously rising.] If we celebrate the victory in a song contest with such hap[p]iness, I can imagine how grandiose the celebration ... of our victory in Karabakh [will be]" (qtd. in Muradova).

This symbiotic relationship between politics and music is apparently not unique to Azerbaijan, for, to use Fareed Zakaria's wording, "[m]usic competitions, like big sporting events, are often proxies for larger disputes or trends" (Zakaria). As Ilham Aliyev, the incumbent President of Azerbaijan, has aptly noted in his reference to the Eurovision Song Contest and Azerbaijan's participation in it, "in today's world... [one never] know[s] where the song ends and politics [begins]" (Ilham Aliyev: 'Our Future"'). Perhaps not surprisingly, the ESC - and Azerbaijan's successful engagement therewith - served to provide yet another thematic platform upon which a discursive confrontation between Yerevan and Baku came to unfold ("An Abuse of Stupidity;" "Yerevan's Political Indigestion"); a confrontation that ended up perhaps not unexpectedly for many observers - with Armenia's ultimate withdrawal, in March 2012, from the contest's Baku-based edition. ${ }^{33}$

This being so, the post-ESC interest that Azerbaijan's artistic community could come to develop in the external market, more regularized engagement and professionalized contact that the national artists would subsequently move to cultivate with the international cultural community, and a new, externally defined, discursive universe into which they would consequently evolve - a currently unfolding trend some instantiations of which have been cited above - are likely to work to gradually prompt the country's cultural field to move conceptually beyond the framework imposed by the conditions of war.

While the full implications of such a delinking remain to be seen, the latter possibility should not be taken to imply that the country's cultural diplomacy would stop serving to support the country's foreign policy agenda. What it may result in, though, is that the international public support the country's cultural capital is certain to garner will no longer be a part of a thoroughly strategized programmatic effort in that direction, but rather will be a function of unintended effects cultural workings will serve to produce. And the latter, by sheer virtue of the genuine and uncontrolled character of its dynamics, is likely to prove more powerful in its unintended spin-offs than the former ever would in its pre-conceived outcomes.

It has been nearly two decades that Azerbaijan has drawn on the country's vast energy resources to build the domestic and international components of state identity, indeed its legitimacy. With its oil resources soon to be depleted and, consequently, the 
government now seeking to move away from oil as the sole source upon which to build state legitimacy at home and abroad and around which to construct state identity, Baku started to look to the country's national culture as an effective backbone by and through which to underpin both. That being so, the ESC - as one of the mechanisms through which the state sought to garner social capital abroad through mobilizing cultural capital at home - has worked to open up the channel through which indigenous cultural elements have found themselves susceptible to the influences of international cultural forces. The quest to use domestic cultural capital to build social capital abroad, therefore, has effectively worked to open up the ways in which the cultural capital itself has come to be subject to an external influence, indeed modification. By virtue of that influence, Azerbaijan's successful participation in the ESCs, furthermore, is likely to render the evolving dynamics within the country's cultural realm and the very process of its post-colonial identity formation, as well as the nature of its cultural diplomacy, detached from the demands that the country's domestic and foreign policy dictates and have them develop the logic of their own - one rooted in, deriving its agency from, and serving the purposes of the internal progression within the cultural field itself. In short, what was meant to influence has now come to be influenced by sheer virtue of the workings of the mechanism through which its influence was to be effected. And it is these latter parameters within which Baku's ESC-2011 victory - and the developments that followed - is bound to bear a powerful impact on processes of state formation and nation building in Azerbaijan at a crucial juncture when the state is seeking to define the contours of its national particularity.

\section{Notes}

1. Murad Ismayilov is a doctoral student in Sociology at the University of Cambridge and the Editor-in-Chief of the Azerbaijan Diplomatic Academy's biweekly online publication Azerbaijan in the World. He holds an MSt in International Relations (2009) from the University of Cambridge and an MA in International Relations from the Baku State University (2004). In 2005, he completed a four-month NATO Senior Executive Program at the NATO Studies Center in Bucharest (Romania). His research interests include international relations/political theory (with a focus on constructivist and post-structuralist approaches), sociology and political economy of post-Soviet transition, national identity and state-society relations (with a regional focus on Azerbaijan and post-Soviet Eurasia), as well as sociology and security of the Middle East. He has authored a number of academic articles and book chapters, including placements in refereed journals and edited volumes.

2. See, for example, Gould; McLaughlin; "Alexander Rybak." Cf.: "Activists Seek Eurovision Conscience;" Neukirch; McGuinness; Abbasov; G. E.; Taylor; "Eurovision Puts Spotlight."

3. Explore http://www.google.com/insights/search (19 June 2012). Also see "Search Queries on "Azerbaijan."'

4. As many others within the Baku government, Mehriban Aliyeva, the country's First Lady, for example, viewed Baku's role as host of the ESC-2012 as a chance to exhibit the "history and culture" of "ancient and rapidly developing Azerbaijan" ("Eurovision 2012"). Likewise, for Fuad Alaskarov, head of the department for work with law enforcement agencies of Azerbaijan's Presidential Administration, Eurovision and Baku's hosting of it was an opportunity to have "millions of people" watching the televised version of the contest witness Azerbaijan's being "a rapidly developing, free, tolerant nation with ancient and rich culture" ("Security Provision During the Eurovision Contest"). Elmar Mammadyarov, the country's foreign minister, concurs, openly admitting in an opinion article for The Wall Street Journal that, “Azerbaijan's pride in hosting the 2012 Eurovision Song Contest ... reflects far more than a love of music. It signals my country's re-emergence into the international community and enables us to showcase our achievements since independence" (Mammadyarov). For other similar opinions, also see "Foreign Ministry: 'Eurovision Enabled;"” "Presidential Administration: 'Eurovision Guests."”

5. Apart from and in addition to this record, over the five years of its involvement with Eurovision, Azerbaijan would always conclude the competition as one of its top ten finalists (indeed, among 
the top five finalists over the last four years of its participation), the only country to have done so during the contest's entire history.

6. The text for Azerbaijan's ESC-2008 entry was written by Zahra Badalbeyli, while the music was composed by Govhar Hasanzade, both being Azerbaijani nationals. For the original lyrics, see http://www.eurovision.tv/event/lyrics?event=1468\&song=24503 (31 Jan. 2012).

7. Among the notable international events that Azerbaijan has to date hosted are, for example, the International Jazz Festival annually held in Baku since 2005; the International Mugham Festival staged in Baku twice, in 2009 and 2011; the International Music Festival annually organized in Gabala since 2009; the 2007 World Wrestling Championship held in Baku; the International Mstislav Rostropovich Music Festival annually hosted in Baku since 2007.

8. Not surprisingly, the majority of the hotels Baku features are of five to four star category only and, as such, have been designed and meant primarily for visitors of a higher social standing, while the availability of low-to-medium priced accommodation had thus far been very limited.

9. The largest live audience to have ever attended the Eurovision contest - their number having neared 38,000 people - was attracted by the ESC-2001 in Copenhagen, while the ESC-2011 in Duesseldorf (Germany) attracted a live audience of some 36,000 people, as well as over 114 million television and web viewers. For some related statistics, see http://www. eurovision.tv/page/history/facts-figures and http://esc2011.webs.com/apps/blog/show/ 7240742-114-5-million-people-watched-the-eurovision-song-contest-2011- (23 June 2012).

10. See http://www.fco.gov.uk/en/travel-and-living-abroad/your-trip/eurovision (23 June 2012).

11. "A Eurasian Enigma Lifts Its Veil." For the complete list of countries that applied to be represented in the ESC-2012, see "43 Countries." Following Armenia's withdrawal from the contest on March 7, 2012, the number of countries to compete at the Eurovision contest in May '12 dropped to 42 ("Armenia Withdraws").

12. In an effort to encourage an ever greater number of tourists to visit the country during the Eurovision week in May 2012, the Azerbaijani authorities moved to simplify the country's visa regime for those intent on attending the ESC (Eurovision ticket holders, accredited individuals, and invited guests, that is), making it possible for the latter group to obtain a visa on the border and do so at a lower than usual rate. To the same end, the government took steps towards simplification of other logistical elements associated with the tourists' travel to and stay in Baku, including the hotel logistics. The construction of a number of low-to-medium priced accommodation - still allegedly not sufficient - was a part of efforts in this direction. For details on the simplified visa regime, see "Details on Visa." The government's ambitions with regards to its tourist potential reach beyond the confines of Eurovision, however, the country's joining the UN World Tourism Organization (UNWTO) and the World Travel \& Tourism Council (WTTC) in late November 2011 expressive of the latter commitment. As such, Baku is currently working on a number of large-scale projects meant to gradually turn the country into a mass tourist destination in the region. Among the latter is a new mountain Shahdag ski resort complex in the north of the country due to open in late 2012 and set to attract some 5,000 visitors daily. See Weaver; "Doha, Baku, Promote." For the current plans to expand the existing network of Azerbaijan Airlines in Europe and Asia, see "Azerbaijan Airlines Expands."

13. For a conceptualization of Eurovision as a media event, see Dayan and Katz.

14. Indeed, one can easily detect a growing sense of pride among state officials and many members of the general public for some outstanding development indicators their country has displayed over the past several years, including - and particularly - for many of the latter's visible manifestations of which the ESC victory is widely taken to be an indicative one. In what highlights just that, Elchin Efendiyev, Azerbaijan's deputy prime-minister, stated - following immediately the country's successful performance in the Eurovision contest - that "Eurovision victory does not merely amount to a propaganda of Azerbaijani culture, but it is also an indicator of progress our country had registered and a bright manifestation of its achievements deserving of respect" ("Elchin: Eurovision Victory Is a Propaganda"). Fakhraddin Gurbanov, Azerbaijan's Ambassador to the United Kingdom, in turn, in his response to government critics - and in light of the ESC-2011 victory his country has just registered - noted with beaming pride that "in the past 20 years we have transformed our economy from a post-Soviet basket case into one of the fastest growing economies in the world... [and 2011] sees the opening not only of the new Kempinski, Hilton and Marriotts in Baku, but also the Four Seasons. Transformation indeed!" (Gurbanov). 
15. According to Sietse Bakker, the ESC event supervisor, some 1,000 journalists traveled to Baku in May 2012 to attend, and subsequently report on, the ESC's 2012 cycle ("Sietse Bakker: 'Baku Crystal Hall'").

16. Interestingly, the Eurovision contest known for its popularity with the LGBT communities across Europe, the wide anticipation of the ESC-2012 has ignited the first wave of open discussion in national online media as to the overall situation with, and the society's attitudes towards, the country's sexual minorities, particularly in light of the latter's rather traditional outlook and, consequently, widely held concerns among international observers about its record on gay rights, on one hand, and Baku's long history of ethnic and religious tolerance, on the other (Isayeva; "Gay Parade in Baku"). The period following Azerbaijan's ESC-2011 victory also witnessed the launch of the LGBT website, the first of its kind in Azerbaijan and indeed in the entire Caucasus ("Website for Homosexuals Launched"). For comments by senior state officials on the issue, see, for example, "The Administration of President of Azerbaijan On Details."

17. The government's quest for balanced representation in Western media found expression in the words of Elman Abdullayev, the spokesperson for Azerbaijan's foreign ministry, for example, who, in one of the press conferences he gave ahead of the Eurovision final his country hosted, stated explicitly that his "government was willing to hear criticism but also wanted recognition for its achievements and its willingness to open up to the rest of the world" (Herszenhorn). For some instantiations of Western attitudes towards Azerbaijan in light of the latter's Eurovision victory, see, for example, reactions at http://www.esctoday.com/news/read/17445?id= 17445\&offset=432\#reactions (23 June 2012). For an Azerbaijani reaction to what many in Baku viewed as "discriminatory" representation of the nation by the West following the country's ESC-2011 victory, see, for example, Aslanov. For examples of negative coverage of Azerbaijan by Western media in light of the Eurovision contest the country hosted, see, for example, Neukirch; Langer; Mayr; Goncharenko; Gogia; Edwards; “"They Took Everything From Me;”” "Azerbaijan: Opposition Activist Freed;" "Political Legitimacy;" G. L.; Mock; Hale; Lunacek. For an attempt at balanced coverage, see, for example, Bryza; "A Eurasian Enigma Lifts Its Veil."

18. For the government's reaction to some earlier instantiations of pro-democracy criticism of its performance, see, for example, Mamedov; "Security Provision;" "President's Office: "Freedom of Press Is Fully Guaranteed;", "Ali Hasanov: 'The Baku Government Condemns;"” "Parliamentarian Pointed to Reasons."

19. "Speaker: 'The Grandiose Success of Eurovision."” Also see "Milli Majlis Speaker Forwarded a Letter of Protest;" "Azerbaijani Parliament Passed a Letter of Protest;" "Azerbaijan's Presidential Administration Accused;" "Azerbaijan's MFA Accused the European Parliament;" "Parliamentarian Calls On the Revision of Relations."

20. Abulfas Garayev, Azerbaijan's Minister of Culture and Tourism. Qtd. in "Eurovision is Going to Improve."

21. See for example the notes to this effect by Leyla Aliyeva, the chair of Azerbaijan Youth Organization of Russia (AMOR) and the editor of the journal of the same name, in "Leyla Aliyeva: 'Eurovision-2012 is a Wonderful Opportunity."” Also, see "An Azerbaijani Minister Denies Rumours;" Gurbanov. The Baku government has now also engaged in wide production of cultural artefacts and the various relevant infrastructure - the latter ranging from a 160-page brand new touristic atlas of the capital and the first-of-its-kind "Azerbaijan Pages" Apple iPad/ iPhone/iPodTouch application, for example, to the openings of a range of new, including five-star, hotels and the motto chosen for the ESC's 2012 cycle reading "Light Your Fire," credit to the country's (the latter itself often referred to as the "Land of Fire") historical association with fire - meant to popularize the country and increase awareness about it among the potential tourists and average observers whose attention it hopes the ESC-2012 would garner. See "A Touristic Atlas of Baku Published;" Siim; "A Free AzerbaijanPages Application." For more information on the "Azerbaijan Pages" Apple application, see the official webpage at http://azerbaijanpages.az (2 Feb. 2012).

22. Sebastian Vinther, a guitarist for Denmark's 2011 entry. Qtd. in Peter.

23. Running Scared, the Azerbaijani entry for the ESC-2011, was internally selected from 70 songs by the national professional jury. See http://www.esctoday.com/news/read/17020?id= 17020\&offset=486 (2 Feb. 2012).

24. Part of Baku's recently activated efforts at cultural diplomacy, the exhibition - displaying the artistic work of 21 Azerbaijani artists - was supported by the Heydar Aliyev Foundation, a 
non-governmental organization headed by the country's First Lady and UNESCO Goodwill ambassador Mehriban Aliyeva and set to promote Azerbaijani art and culture abroad. For the information on the exhibition, see the official press-release for the London-based cycle at http://www.phillipsdepury.com/press/2012/uk-fly-to-baku.aspx?year=2012 (1 Feb. 2012). Also see "The 'Fly To Baku. Contemporary Art of Azerbaijan' Exhibition Opened;" "Mehriban Aliyeva: 'The Key Objective;"” "Eurovision Winners Enjoy." For a comment by a Western observer on Azerbaijani artistic forms staged in London and beyond, see, for example, Krupinska. For Krupinska's insights into her broader engagement with Azerbaijani culture, also see her blog entry at http://silviakrupinska.wordpress.com/2011/12/23/my-visitof-azerbaijan (1 Feb. 2012). For further information on the Heydar Aliyev Foundation, see the organization's official website at http://www.heydar-aliyev-foundation.org/index_e.html (1 Feb. 2012).

25. Among Azerbaijani performers of mugham, Alim Qasimov - also a member of the International Assembly of Rare Voices - is the most renowned and indeed most popular with the Western audience. He is also one who has frequently performed jointly with Western artists, including with the US-based Kronos quartet, the latter having cooperated with some other Azerbaijani artists as well, including with Firangiz Alizade, yet another renowned Azerbaijani performer of mugham. Among Azerbaijani jazz singers, Aziza Mustafa Zadeh is by far the most famous in Europe and across the world. For further information on Aziza Mustafa Zadeh, see Mustafa Zadeh and Blair. Also see her official website at http://www. azizamustafazadeh.de (2 Feb. 2012). For a fine analysis of Alim Qasimov's work, see Faig gizi. Also see Baghirova; Buker; "Azerbaijan's Mugham Performers." For further information on the Kronos Quartet, see their official website at http://kronosquartet.org (2 Feb. 2012).

26. Indeed, the use of Azerbaijani in outdoor advertising in the country allegedly dropped by $56 \%$ in 2011 , with the use of English in the latter grown by the same measure (" $63 \%$ of Outdoor Advertising").

27. As Novruz Mammadov, head of the foreign relations department of Azerbaijan's Presidential Administration, reflecting on the victory his country registered at the ESC-2011, noted, "It was not merely a victory in a competition. Rather, Azerbaijan has proven that it could score high among the European nations in culture, arts, and other humanitarian fields" ("The Administration of President of Azerbaijan Accused").

28. In what is indicative of Eurovision's immediately tangible "westernising" effects within the country's broader social domain, many of the public servicemen, including experts of the Baku city ambulance and emergency medical care, the Baku police, and the taxi drivers alike - in anticipation of Baku's hosting of Eurovision-2012 - were set to engage in intensive English language training shortly after the country scored a victory in the ESC-2011 ("Baku 2012: Year of Eurovision").

29. See Eldar Mansurov's official page at http://eldarmansurov.az/en (24 June 2012).

30. For some reflections on a distinction between "mainstream" and "peripheral" - if not necessarily indigenous - culture within Azerbaijan's overall cultural domain, see, for example, Ismayilova.

31. I am grateful to the anonymous reviewer for calling attention to, indeed inspiring consideration of, this possibility.

32. For different programs and activities run by the Karabakh Foundation, consult the organization's official website at http://www.karabakhfoundation.org (31 Jan. 2012).

33. As a major reason behind the decision to withdraw, Yerevan cited the statement Azerbaijani President made a few days earlier that "[o]ur main enemies are Armenians of the world and the hypocritical and corrupt politicians under their control" ("Armenia Pulls Out"). For a fine analysis of the discursive and political context in which Armenia decided to withdraw, see for example Krikorian. For comments by representatives of Azerbaijan's political and social scene on Armenia's withdrawal, see for example "An MP: 'Armenia is Afraid;" Tariverdiyeva; "An MP: 'Armenia's Non-Participation in the ESC;" Hamidov. As a matter of penalty for the late withdrawal from the ESC, Armenia's national broadcaster had to pay "their regular participation fee towards the show - plus an extra 50\% of this fee." Besides, the state channel was set to "broadcast all three shows of the competition live, with no interruptions" (Nuhiu). 


\section{References}

Abbasov, Shahin. “Azerbaijan's Eurovision's Story: Great Chances to Improve, But No Political Will." Caucasus Analytical Digest 32. 5 (December 2011): 2-4. Print.

“Activists Seek Eurovision Conscience." View and News from Norway, 30 January 2011. Web. 22 June 2012.

“A Eurasian Enigma Lifts Its Veil: What Eurovision Told the World about Azerbaijan." Caspian Information Centre, Occasional Paper, No. 20, June 2012. Web. 23 June 2012.

"A Free AzerbaijanPages Application for iPhone, iPad, and iPod Touch Created in the Run-up to Eurovision.” Day.az, in Russian. 26 January 2012. Web. 2 Feb. 2012.

"Alexander Rybak: Eurovision in Baku Is Going to Be Grandiose." Day.az, in Russian. 26 January 2012. Web. 22 June 2012

"Ali Hasanov: "The Baku Government Condemns the Politicization of the Eurovision Contest." Day.az, in Russian. 24 May 2012. Web. 23 June 2012.

Altman, Diana. "May I Introduce Azerbaijan? The Karabakh Foundation's Individual Approach to Cultural Diplomacy." Azerbaijan in the World IV.12 (15 June 2011): 5-7. Web. 31 Jan. 2012.

Amani, Aslan. "Eurovision Can Transform Azerbaijan." The Guardian, 17 May 2011. Web. 29 Jan. 2012.

“An Abuse of Stupidity, Or How Armenian Propaganda 'Defames' Eurovision 2012.” Day.az, in Russian. 28 October 2011. Web. 3 Feb. 2012.

"An Azerbaijani Minister Denies Rumours of Billions Spent on Eurovision." Day.az, in Russian. 13 December 2011. Web. 2 Feb. 2012.

"An Azerbaijani Singer to Sing a Duet with the Croatian Representative at Eurovision." Day.az, in Russian. 24 April 2012. Web. 4 May 2012.

"An MP: 'Armenia is Afraid of Shame in the ESC-2012."” Day.az, in Russian. 7 March 2012. Web. 3 May 2012.

“An MP: Armenia's Non-Participation in the ESC in Baku Will Hit Armenia Itself." Day.az, in Russian. 7 March 2012. Web. 3 May 2012.

"An NGO 'Eurovision' Headquarters Group is to Be Set Up in Azerbaijan.” Day.az, in Russian. 24 January 2012. Web. 3 Feb. 2012.

Antidze, Margarita. "Azerbaijan's People and President Praised Their Victorious Eurovision Song Contest Duo." Reuters, 16 May 2011. Web. 2 Feb. 2012.

"Armenia Pulls Out of Azerbaijan-hosted Eurovision Show." BBC News, 7 March 2012. Web. 3 May 2012.

“Armenia Withdraws from Eurovision 2012!” Eurovision News, 7 March 2012. Web. 23 June 2012.

Aslanov, Aslan. "Victory in the Eurovision Song Contest-2011 is a Success of Entire Azerbaijan." Day.az, in Russian. 21 July 2011. Web. 23 June 2012.

“A Touristic Atlas of Baku Published.” Day.az, in Russian. 31 January 2012. Web. 2 Feb. 2012.

"Azerbaijan Airlines Expands Network as Azerbaijan Aims to Raise Tourism Profile." CAPA Centre for Aviation, 14 June 2012. Web. 13 Aug. 2012.

"Azerbaijan: Opposition Activist Freed as pre-Eurovision Hunger Strike Begins." Amnesty International, Press Release, PRE01/256/2012, 16 May 2012. Web. 23 June 2012.

"Azerbaijani Parliament Passed a Letter of Protest Against the European Parliament Resolution." Day.az, in Russian. 29 May 2012. Web. 24 June 2012.

“Azerbaijan's MFA Accused the European Parliament of an Unfair Approach.” Day.az, in Russian. 25 May 2012. Web. 24 June 2012.

“Azerbaijan's Mugham Performers Will Join with the US Classical Quartet.” Day.az, in Russian. 16 November 2012. Web. 2 Feb. 2012.

“Azerbaijan's Presidential Administration Accused the European Parliament of Bias." Day.az, in Russian. 25 May 2012. Web. 24 June 2012.

Baghirova, Sana. "Azerbaijani Mugham: Declared Masterpiece of Oral World Heritage by UNESCO.” Azerbaijan International 11.4 (Winter 2003): 25. Web. 2 Feb. 2012.

"Baku 2012: Year of Eurovision.” Trend.az, 28 December 2011. Web. 2 Feb. 2012.

Barry, Ellen. "Eurovision Joy Deflects Cares for a While." The New York Times, 15 May 2011. Web. 31 Jan. 2012.

Bryza, Matthew. "Eurovision Could Prompt Azerbaijan to Change Tune.” Bloomberg, 25 May 2012. Web. 23 June 2012.

Buker, Samantha. "Kronos Quartet and Alim Qasimov." The Washington Post, 19 February 2012. Web. 2 Feb. 2012. 
“Can Eurovision Burnish Azerbaijan's Image?” Spiegel International, 15 May 2011. Web. 2 Feb. 2012.

“43 Countries Represented at Eurovision in 2012.” Eurovision News, 17 January 2012. Web. 23 June 2012.

“Danish Songwriter Headhunted by Azerbaijan's Nikki." Eurovision News, 2 March 2012. Web. 4 May 2012.

Dayan, Daniel, and Elihu Katz. Media Events: The Live Broadcasting of History. Cambridge, Mass: Harvard UP, 1992. Print.

"Details on Visa and Accreditation for Baku." Eurovision News, 10 February 2012. Web. 4 May 2012.

"Doha, Baku, Promote 2020 Summer Games Bids." GamesBids.com, 12 January 2012. Web. 13 Aug. 2012.

Edwards, Haley. "Power Ballad." Foreign Policy, 24 May 2012. Web. 23 June 2012.

"Elchin: Eurovision Victory is a Propaganda of Azerbaijani Culture and an Indicator of Our Country's Progress." Day.az, in Russian. 16 May 2011. Web. 2 Feb. 2012.

Erickson, Amanda. "In Baku, a Citywide Coming-Out Party for Eurovision." The Atlantic Cities, 27 January 2012. Web. 2 Feb. 2012.

European Parliament Resolution of 24 May 2012 on the Human Rights Situation in Azerbaijan, 2012/2654(RSP). Web. 24 June 2012.

"Eurovision 2011 Winner Talked about His Engagements on Facebook." Day.az, in Russian. 19 February 2012. Web. 20 Feb. 2012.

"Eurovision 2012: In Anticipation of a Great Feast." Trend.az, in Russian. 19 March 2012. Web. 23 June 2012.

"Eurovision is Going to Improve Azerbaijan's Image." Day.az, in Russian. 26 January 2012. Web. 2 Feb. 2012.

"Eurovision Puts Spotlight on Azerbaijan Human Rights." BBC News, 23 March 2012. Web. 22 June 2012.

"Eurovision Winner Eldar Revealed the Details of the Family Biography." Day.az, in Russian. 16 June 2011. Web. 3 Feb. 2012.

"Eurovision Winners Enjoy Fly to Baku Exhibition." News.az, 19 January 2012. Web. 1 Feb. 2012.

Ewing, Jack. "Singers from Azerbaijan Win Eurovision Contest." The New York Times, 15 May 2011. Web. 22 June 2012.

Faig gizi, Natavan. “Alim Qasimov: Azerbaijan's Golden Voice.” Visions of Azerbaijan 3.1 (Winter 2008): 68-76. Web. 2 Feb. 2012.

"Foreign Ministry: 'Eurovision Enabled Azerbaijan to Showcase Its Potential."” Trend.az, 27 May 2012. Web. 23 June 2012.

“Gay Parade in Baku: To Be Or Not To Be?” News.az, 12 January 2012. Web. 30 Jan. 2012.

G. E. "Can Engelbert Humperdinck Free Azerbaijan?" The Economist, 2 March 2012. Web. 22 June 2012.

Gellner, Ernest. Nations and Nationalism. Ithaca, NY: Cornell UP, 1983. Print.

G. L. "Songs, But Not Of Freedom.” The Economist, 28 May 2012. Web. 23 June 2012.

Goble, Paul. "Azerbaijani Eurovision Victory Puts Baku in a New League." Azerbaijan in the World 4.10 (15 May 2011). Web. 2 Feb. 2012.

Gogia, Giorgi. "Eurovision: The View from a Courtroom.” The Wall Street Journal, 23 May 2012. Web. 23 June 2012.

Goncharenko, Roman. "Eurovision Spotlights Human Rights in Azerbaijan." Deutsche Welle, 17 May 2012. Web. 23 June 2012.

Gould, Kevin. "Baku and Beyond: A Road-Trip around Azerbaijan." The Guardian, 21 May 2011. Web. 22 June 2012.

Gurbanov, Fakhraddin. “All Change in Azerbaijan Long before Eurovision.” The Guardian, 20 May 2011. Web. 2 Feb. 2012.

Hale, Jacqueline. “Azeri-vision.” European Voice, 25 May 2012. Web. 23 June 2012.

Hamidov, Hamid. "Armenia Withdraws from Eurovision. The Armenians are Deprived of the Feast." Day.az, 7 March 2012. Web. 3 May 2012.

Herszenhorn, David M. "Welcoming Eurovision, but Not the Scrutiny." The New York Times, 23 May 2012. Web. 23 June 2012.

"Ilham Aliyev: 'Our Future is in Our Hands.” Al Jazeera, Frost Over the World, 16 October 2011. Web. 2 Feb. 2012. 
"Interest for Azerbaijan Heightened in Google." Day.az, in Russian. 30 June 2011. Web. 2 Feb. 2012.

"Interest in Azerbaijan Up by a Whopping 4,662\% Following their Eurovision Success." Breaking Travel News, 16 May 2011. Web. 2 Feb. 2012.

Isayeva, Ulker. "On Homosexuality and Tolerance.” Inews.az, in Russian. 26 January 2012. Web. 30 Jan. 2012.

Ismayilova, Khadija. "Azerbaijan: Baku's Deep Pockets for Art Abroad Contrasts with Restrictions at Home." Eurasianet.org, 4 November 2011. Web. 2 Feb. 2012.

Ismayilov, Murad, and Michael Tkacik. "Nation-Building and State-Building in Azerbaijan: The Challenges of Education Abroad." Turkish Policy Quarterly, (Winter 2009/2010): 89-104. Print.

Krikorian, Onnik. "Opinion Divided on Armenian Withdrawal from Eurovision." Ararat, 22 March 2012. Web. 3 May 2012.

Krupinska, Silvia. "Fly to Baku Exhibition and London Art Fair Approaching." Art Review, 15 January 2012. Web. 1 Feb. 2012.

Langer, Annette. "Azerbaijan Flouts Free Press on Eve of Eurovision." Spiegel International, 2 April 2012. Web. 23 June 2012.

"Leyla Aliyeva: 'Eurovision-2012 is a Wonderful Opportunity to Tell about Our Country, Culture, Traditions, and History."” Day.az, in Russian. 8 June 2011. Web. 2 Feb. 2012.

Lunacek, Ulrike. "EU Will Monitor Azerbaijan Following Eurovision." Public Service Europe, 31 May 2012. Web. 23 June 2012.

Mamedov, Elman. “Azerbaijan Slams Critics Ahead of Eurovision.” Al Arabiya News, 21 May 2012. Web. 23 June 2012.

Mammadyarov, Elmar. “Azerbaijan's Achievement.” The Wall Street Journal, 23 May 2012. Web. 23 June 2012.

Mayr, Walter. "German Government Report Slams 'State Repression."” Spiegel International, 2 May 2012. Web. 23 June 2012.

McGuinness, Damien. "Evicted in Baku to Make Way for Eurovision." BBC News, 22 December 2011. Web. 22 June 2012.

McLaughlin, Daniel. "East Meets West.” The Irish Times, 26 May 2012. Web. 22 June 2012.

"Mehriban Aliyeva: "The Key Objective of Our Activity is the Popularisation of Azerbaijan, Its Rich Culture, and History."” Day.az, in Russian. 16 April 2012. Web. 1 Feb. 2012.

"Member of Parliament: 'Eurovision 2011 Victory is a Result of Azerbaijan's Rising Profile." Day. az, in Russian. 15 May 2011. Web. 31 Jan. 2012.

"Milli Majlis Speaker Forwarded a Letter of Protest to His European Counterpart." Day.az, in Russian. 26 May 2012. Web. 24 June 2012.

Mock, Vanessa. "Host Scores Well - For Corruption.” The Wall Street Journal, 25 May 2012. Web. 23 June 2012.

Muradova, Mina. "The Political Ramifications of Azerbaijan's Eurovision Victory." Central Asia Caucasus Institute Analyst, 25 May 2011. Web. 25 Apr. 2012.

Mustafa Zadeh, Aziza, and Betty Blair. "Jazz, Mugam and Other Essentials of My Life." Azerbaijan International 4.4 (Winter 1996): 20-23, 71. Web. 2 Feb. 2012.

Neukirch, Ralf. "Azerbaijan Seeks to Burnish Image Ahead of Eurovision." Spiegel International, 4 January 2012. Web. 22 June 2012.

Nuhiu, Rinor. "EBU: Armenia to Face Sanctions for Late Withdrawal.” ESCDaily.com, 2 May 2012. Web. 3 May 2012.

"63\% of Outdoor Advertising in Azerbaijan Written in English and 2\% in Uncertain Language." ABC.az, 21 December 2011. Web. 2 Feb. 2012.

"Parliamentarian Calls on the Revision of Relations with the European Parliament." Day.az, in Russian. 25 May 2012. Web. 24 June 2012.

"Parliamentarian Pointed to Reasons behind Envy towards Azerbaijan." Day.az, in Russian. 24 May 2012. Web. 23 June 2012.

Peter, Savodnik. "Eurovision: Nation Branding via Cheesy Pop Music." Bloomberg Businessweek, 9 June 2011. Web. 2 Feb. 2012.

"Political Legitimacy is About More than Eurovision." The Independent, 23 May 2012. Web. 23 June 2012.

"Presidential Administration: 'Eurovision Guests will See First Hand that Anti-Azerbaijani Publications are Slanderous."” Day.az, in Russian. 15 May 2012. Web. 23 June 2012. 
"President's Office: 'Freedom of Press is Fully Guaranteed in Azerbaijan."” Day.az, in Russian. 16 May 2012. Web. 23 June 2012.

Raykoff, Ivan, and Robert Deam Tobin, eds. A Song for Europe: Popular Music and Politics in the Eurovision Song Contest. Surrey, UK: Ashgate, 2007. Print.

"Search Queries on 'Azerbaijan' are Among the Top Ten Most Popular on Google." Day.az, in Russian. 31 May 2012. Web. 19 June 2012.

"Security Provision During the Eurovision Contest is a Responsibility of Every Citizen of Azerbaijan." Day.az, in Russian. 18 May 2012. Web. 23 June 2012.

"Sietse Bakker: 'Baku Crystal Hall Leaves Behind the World's Most Modern Buildings for Its Composition."” APA, 18 May 2012. Web. 24 June 2012.

Siim, Jarmo. "Baku 2012: Light Your Fire!" Eurovision News, 25 January 2012. Web. 2 Feb. 2012.

"Speaker: 'The Grandiose Success of Eurovision Sparked Envy Among Anti-Azerbaijani Forces.", Day.az, in Russian. 29 May 2012. Web. 24 June 2012.

Tariverdiyeva, Elmira. "Eurovision 2012: Yet Another Failure of Armenian Propaganda." Trend.az, in Russian. 7 March 2012. Web. 3 May 2012.

Taylor, Jerome. "Eurovision: Light Entertainment in a Dark Place." The Independent, 19 March 2012. Web. 22 June 2012.

"The Administration of President of Azerbaijan Accused the Armenian Side of Hypocrisy and Duplicity." Day.az, in Russian. 13 December 2011. Web. 2 Feb. 2012.

"The Administration of President of Azerbaijan on Details of Preparation for Eurovision-2012." Day.az, in Russian. 25 May 2011. Web. 30 Jan. 2012.

"The 'Fly to Baku. Contemporary Art of Azerbaijan' Exhibition Opened in London." Day.az, in Russian. 18 January 2012. Web. 1 Feb. 2012.

"The Number of Tourists Who Visited Baku for Eurovision-2012 Named." Day.az, in Russian. 12 June 2012. Web. 21 June 2012.

“"They Took Everything From Me:' Forced Evictions, Unlawful Expropriations, and House Demolitions in Azerbaijan's Capital." Human Rights Watch, February 2012. Web. 23 June 2012.

Weaver, Courtney. “Azerbaijan Tourism: Eurovision Edition.” Financial Times, 22 May 2012. Web. 13 Aug. 2012.

“Website for Homosexuals Launched in Azerbaijan.” News.az, 21 May 2011. Web. 30 Jan. 2012.

"Yerevan's Political Indigestion, Or How Armenians Defame Eurovision in Baku." Day.az, in Russian. 28 November 2011. Web. 3 Feb. 2012.

Zakaria, Fareed. "Zakaria: The Geopolitics of the Eurovision Song Contest." CNN World, 19 March 2012. Web. 26 Apr. 2012. 